\title{
2005年度日本木材学会生物劣化研究会 “木質構造材料への外国産材の使用にかかわる問題と課題”の概要
}

\section{はじめに}

2005年 3 月 16 日より 18 日までの 3 日間にわた り, 第55回日本木材学会年次大会が京都大学吉田 キャンパス (京都府京都市) で開催された。大会 最終日の18日午後には(社)日本木材保存協会の共催 で生物劣化研究会が開催され, 全国から50名程度 の木材保存の研究者・関係者が参加した。今回は “木質構造材料への外国産材の使用にかかわる問 題と課題”というテーマで, 高耐久性を持つとい われている外国産の樹種に関連する 3 件の講演が あり，それに引き続き様々な方から非常に活発な 討議がなされた。ここではこの講演会の概要につ いて報告する。

講演 1 高耐久樹種の耐久性とファンガスセラー 試験

株式会社ザイエンス 谷川 充氏 高耐久性樹種とされていたボンゴシで作られた

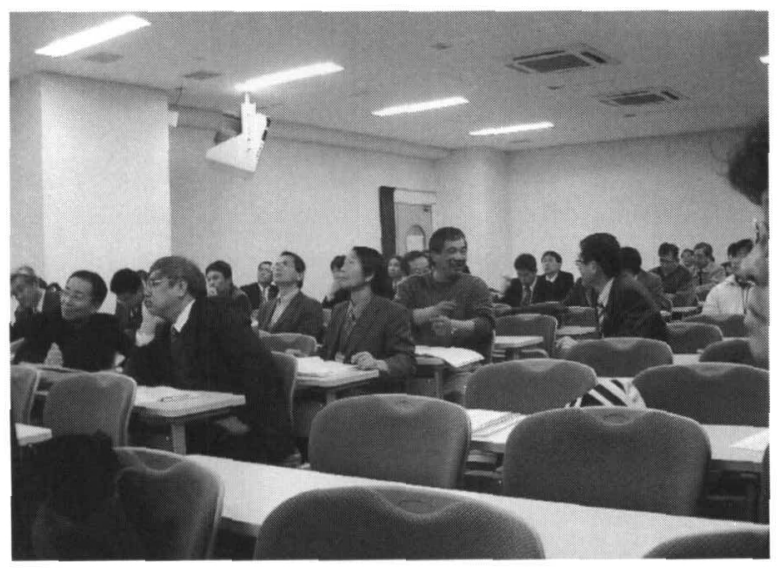

写真 1 会場の様子

\section{土 屋 春 樹*}

木橋が，設置後10年経たずに腐朽によって落下す る事故が起きており，ボードウォークやベンチに 関しても比較的早期の腐朽が認められている。ま た，非常に大きな耐久性を持つとされ，多くの場 所で使用されているイペについても，立木時にお けるものと思われる腐朽が認められている。この ため, 高耐久樹種と呼ばれている樹種について, 改めてその耐朽性の調查をする必要があると考え られる。そこで再現性が高く, 短時間で行える試 験方法として, ファンガスセラーを用いた試験と 野外での小型杭を用いた試験を採用して耐朽性の 評価を行った。試験の評価方法としては, 腐朽操 作 6 ケ月ごとに従来からの目視による被害度の調 查に加えて, 腐朽の進行にともなう質量減少率も 求めた。

その結果, 高耐久性樹種と呼ばれるものの中に は，早期に腐朽が起こり耐用年数に達してしまう ものも見られた。例としてアメリカでは25年以上 の耐用年数を持つとされているジャラやキャブ レーバが, 今回のファンガスセラー試験では 3.5 年 で被害度が2.5に達する結果を示した。

質量減少率を見ると被害度と同様の傾向がある ことを見ることが出来た。しかし，目視による被 害度が 0 の場合でも質量減少率の増加が認められ たこと，また，質量減少率は，腐朽を直接的に数 值で示すことが出来る他, 現実的な強度低下を検 討する指標となり得る可能性を示し, 目視による 被害度と質量減少率の両者を組み合わせることに よって，より正確な情報が得られることが報告さ れた。 


\section{講演 2 外国産材の耐シロアリ性 一統一的評価 基準の作成を目指してー}

京都大学生存圈研究所 吉村 剛氏

アジア・オセアニア地域でのシロアリには類似 点が多く, 共通の評価試験を行えば直接比較が出 来るため有用である。耐朽性については多くの研 究が行われ, 数值としてまとめられている。しか し, 耐蟻性について, 研究は行われているものの 十分にまとめられておらず，特に野外のデータが 不足している。(社)日本しろあり対策協会の仕様や 金融公庫の仕様にも十分な耐蟻性が考慮されてお らず，地域による分類，樹種による分類のみで設 定されている。

海外での耐蟻性試験に目を向けてみると, 大き く分けて質量減少率から判断する方法と質量減少 率と食害指数から判断する方法があった。

日本産材を含む15種類の心材についてヤマトシ ロアリ，イエシロアリを対象とした室内試験及び 野外試験を行った。耐蟻性は密度に影響を受ける と考えていたが必ずしも大きく影響を受けている とはいえないというデー夕が得られた。

マレーシア産材と日本産材の耐シロアリ性比較 を強制掑食試験によって行った。その結果, 生息 域と樹種嗜好性には密接な関係があり, 実際に木 材を使う場所での耐蟻試験の重要性が示された。

\section{講演 3 熱帯産高耐久樹種の使用の現状と今後の 展望}

森林総合研究所 山本幸一氏

高耐久樹種の多くは熱带雨林からの材であり, 違法伐採の可能性が指摘されているものもあるこ とから, 国としても重要な問題であると位置づけ ており，利用に当たっては注意が必要であろう。 現在日本で利用されている高耐久樹種の 8 割程度 がイペであるが，イペの産地である南米（ブラジ ル）から見れば, 日本へ輸出している量的割合は 小さい。アメリカでは, 高耐久樹種を日本の 20 倍 程度使用しており，デッキに使用した場合の耐用 年数は, $\mathrm{CCA}$ 処理材で 40 年なのに対し, イペのデ ッキは25年程度で価格が1.5倍程度とされている。 高耐久樹種は密度が高く成育が遅いと考えられ るため将来的にはワシントン条約で規制されて使 用できなくなる樹種も存在すると考えられる。ま

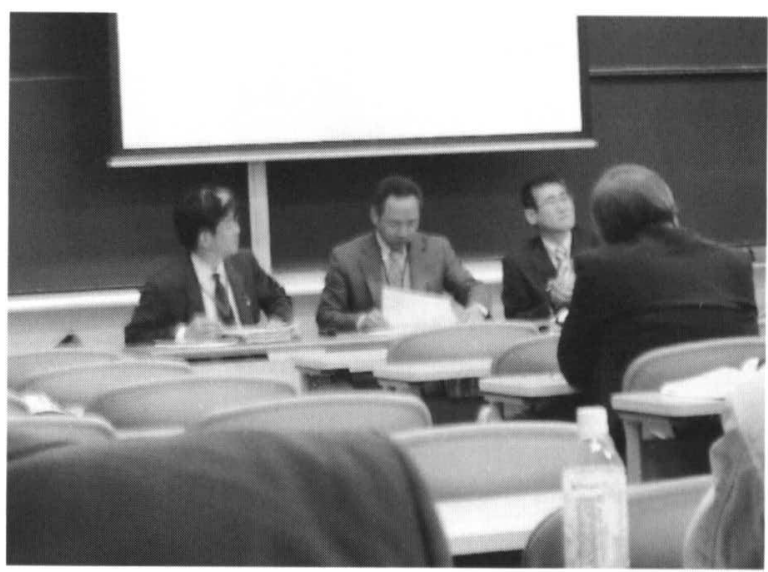

写真 2 左より谷川 充氏, 吉村 剛氏, 山本幸一氏

た, 近年違法伐採への対処として森林認証が導入 され始めている。これにより計画的な伐採と植林 がなされることが期待される。アマゾンに代表さ れるように地域によっては保護区を導入している が, 地域住民の生活への配慮をしない設定により, 国の環境政策と地域経済との間で摩擦が起こって いるところもある。

日本で(社)全国木材組合連合会が意識調査をした ところ, 違法伐採の疑いのある木材を取り扱って いる業者とは取引しないという答えをした業者が ほとんどであったが，顧客はあまり関心を示して いないという結果であった。また，グリーンピー 久等の環境団体や各企業の輸入している材の正当 性を調査するNGOの活動に対しては, その結果 を出来るだけ尊重したいという意見が多かった。

防腐処理木材との住み分けとしては, イペ材の 資源枯渴後の新しい高耐久材樹種の耐朽性に不安 があるという点と, 国産材の使用を進めることを 考えると, 保存処理の利点を強調する必要がある と考えられる。保存処理材に対する理解がまだ低 いことから，これを高めることが必要である。同 時に，10年程度の耐用年数を期待した日本産の高 耐久樹種を育てることも重要であろう。

\section{質疑応答より}

以下に講演後の質疑応答の一部を紹介する。

Q イペ材は使用可能になるまで150～200年かか るということだが，違法伐採でなければ輸入した ほうがよいのか？

A 現在でも日本に輸入はされているが, グリー ンピースの情報等を基に, 違法伐採をしている 


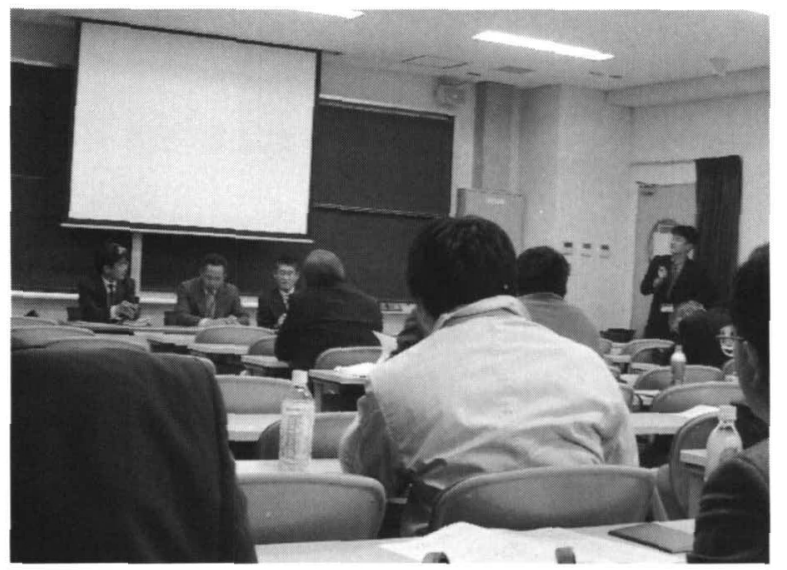

写真 3 質疑応答

メーカー・商社を調べ，注意して使用するように なってきた。品質としては, 以前のものよりも材 質が低下してきている傾向がある。

Aイペについて資源的に継続可能かを考える と，管理された林地から伐採すれば問題ないが, それ以外から伐採すると違法となることから，現 実的には資源の継続性を期待することは難しいの ではないか。

Q イペにはいろいろな商品名がついており実際 に20種程度あるが，それらは一律に高い耐久性が 得られるのか?

A イペと呼ばれるものは16〜18の樹種が総称さ れている。現在使われているものがどの樹種かは 同定されていない。別の例としてセランガンバッ は約30種が総称されている。そして, 初期のもの と現在輸入されているものでは樹種が異なってい る可能性もある。評価をする側としては現在入手 できるものを評価するしかない。

Q 耐シロアリ性の室内試験について 4 週間の試 験期間で評価ができるのか?

A シロアリの場合， 4 週間程度で活性が落ちて しまうため，1 週間から10日程度でも評価が可能 であると思われる。菌とは違いシロアリによる質 量減少は初期に大きく減少すると考えられるの で,より短期間での評価が可能であると思われる。 Q 植林後30年ぐらいで使用が可能な伐期の短い 高耐久性樹種があると聞いたが，詳しい情報がほ
しい。

A ジャラのことであると思われる。この材は オーストラリアで州の管理下で植林・伐採を行わ れている。

Q 熱処理をしたときの耐朽性はどうか？

A 加熱した場合には，揮発しやすい抽出成分の 揮発や熱分解しやすい物質の変性による耐朽性・ 耐蟻性の低下と, 分解産物による腐朽・蟻害の促 進が考えられる。高耐久樹種に対しては加熱処理 の影響は少ないと考えられる。

A ヒバに関しては温度が上がると耐蟻性が下が る傾向がある。

A スギに関しても温度が上がると耐蟻性が下が る傾向がある。テルペノイドの減少が原因ではな いかと考えられる。

A 試験片の大きさによっては大きな影響がある と考えられる。

Q なぜ熱帯産の高耐久性樹種を使う必要がある のか?

A 外構材としてはスギが最も多く使用されてい るが，強度的に不安がある場所に高耐久樹種を使 用する例がある。量的にはスギが 6 ～ 7 割程度で あるのに対し高耐久性樹種が $2 \sim 3$ 割の使用であ る。実際には，階段等の磨耗の多い部分に使うな どデザインの問題だけでなく強度が必要なところ に使用している。

Q イペなどの高耐久樹種には注入処理はしない のか?

A 高耐久樹種の密度は 1 を超えているものが多 く, 空隙率は $10 \%$ 程度である。そのため防腐処理 をしても注入薬剤の絶対量が少ないため, 処理効 果は発揮しにくいものと考えられる。

Q 輸入材と国産材の防腐処理材のエネルギーコ ストはどうか?

A 輸入材のほうがエネルギーコストは高いと考 えられる。計算方法もあるが，耐用年数等の考慮 はされていないと思われるので，それらも含めた エネルギーコストを考えなくてはならない。

(2005. 4.17受付) 